\title{
A Research Agenda for K-12 School- based Service-Learning: Academic Achievement and School Success
}

\author{
Andrew Furco
}

This article was originally published at:

https://journals.sfu.ca/iarslce/index.php/journal/article/view/51/16

Recommended Citation

Furco, A. (2013). A Research Agenda for K-12 School-based Service-Learning: Academic Achievement and School Success. International Journal of Research on Service-Learning and Community Engagement, 1(1). 11-22. 


\title{
A Research Agenda for K-12 School-based Service-Learning: Academic Achievement and School Success
}

\author{
Andrew Furco \\ University of Minnesota
}

In this climate of assessment and accountability, stronger and more convincing evidence of the impacts of service-learning participation on students' test performance and overall academic achievement is needed in order to garner the levels of institutional support necessary for servicelearning to thrive in K-12 education. Not having the proof that verifies a strong link between servicelearning participation and positive academic achievement limits the ability to make the case for implementing service-learning in primary and secondary schools.

Almost all of the service-learning research reviews and agendas published to date include some discussion on the relationship between service-learning participation and academic outcomes. Yet, while a number of research studies have explored this relationship, "the research evidence about service-learning's impact on student learning is not robust enough, or of high-enough quality, to convince skeptics of service-learning's efficacy" (National Service-Learning Partnership, 2003). This is despite the fact that since 2000, the number of service-learning studies has more than doubled.

Whereas there were approximately 200 published studies of service-learning in 2000, today there are at least 500 cited in the literature. ${ }^{1}$ Of these studies, about $15 \%$ (74 studies) focus on issues concerning the impacts of service-learning on primary and secondary (i.e., K-12) students and 28 of these include assessments of student academic outcomes (including school success). ${ }^{2}$ Overall, the findings of these studies indicate generally positive student outcomes in the areas of subject matter learning, standardized test performance, school attendance, earned grades, motivation for learning, and engagement in school. Yet, despite these positive findings, skepticism regarding the academic merits of service-learning persists.

Much of this skepticism stems from the fact that the overall quality of the extant research on K12 service-learning is generally poor. The research has long been criticized for lacking rigor, appropriate detail, and valid measures (Billig \& Waterman, 2003), and a call for "more and better research" has been a constant refrain in the service-learning field. Although the quality of the research has improved in recent years, very few studies of K-12 service-learning have met the highest standards of scientific inquiry. In a recent Organisation for Economic Co-operation and Development-led review of pedagogies that promote innovative learning environments, servicelearning was the pedagogy that had the weakest research. The other pedagogies that were reviewed-which included inquiry-based learning, cooperative learning, problem-based learning, and others-were supported by a strong research base (e.g., a body of replicated, randomized, controlled investigations) that helped make a more convincing case for the academic merits of those practices.

Today, after almost 30 years of service-learning research, the field is still confronting the need to prove that service-learning has positive effects on students' academic achievement and school success. And on the heels of the tenth anniversary of the annual International Research Conference on Service-Learning (and Community Engagement), which was established to help raise the quality of service-learning research, researchers and practitioners still seek higher-quality research studies that can make the case for K-12 service-learning. 
This research agenda report provides: (a) a brief summary of what we know about servicelearning's impact on academic achievement and school success, (b) an overview of some of these issues that undergird the prevailing skepticism about service-learning, and (c) recommendations for strengthening the quality and rigor of the research in order to garner the evidence necessary to make the case for service-learning.

\section{Existing Research on Academic Achievement and School Success}

In regards to academic outcomes, the extant body of research suggests that when done well, servicelearning has the potential to enhance students' understanding of academic content, raise grade-point averages, improve school attendance, and enhance students' performance on standardized tests.

\section{Improved Subject Matter Learning and Performance}

Because of the important role that standardized subject matter examinations play in the education of primary and secondary students, several researchers have explored the relationship between servicelearning and students' performance on subject matter examinations. The findings from several quasiexperimental studies suggest that service-learning can have positive effects on students' subject matter learning and their performance on subject matter examinations and assessments.

For example, Weiler, LaGoy, Crane, and Rovner (1998) assessed differences in reading and language arts performance between a group of primary and secondary school students $(n=775)$ enrolled in 12 classrooms that offered service-learning and a group of students $(n=310)$ from eight comparable classrooms that did not offer service-learning opportunities. To assess the true effect of academic service-learning, this study concentrated on 15 classrooms in which service-learning was well-designed and well-implemented, based on a set of established quality indicators. To establish comparison sites, the researchers identified eight other non-service-learning classrooms that had characteristics (e.g., grade level, nature of study body, etc.) similar to the service-learning classrooms. The data collected included scores on students' subject matter achievement tests, student surveys assessing students' attitudes toward school and community service, and researchers' observations of classroom practice. The study findings revealed statistically significant differences between the two research groups, with service-learning students outperforming the non-servicelearning students in the reading and language arts portions of a standardized state examination (i.e., California Test of Basic Skills). In addition, the students engaged in service-learning reported they had learned more in their service-learning classes than in non-service-learning classes at their school.

Findings from several other studies support Weiler et al.'s (1998) conclusions regarding the impact of service-learning on students' performance on subject matter examinations. In their respective studies, Akujobi and Simmons (1997), Klute and Billig (2002) and Kraft and Wheeler (2003) all found significant improvements in reading and language arts among service-learning participants when compared to a comparable group of students not engaged in service-learning. Other researchers have noted similar positive academic impacts from service-learning participation in other subject areas, including mathematics (Melchior \& Bailis, 2002), science (Klute \& Billig, 2002), and social studies (Meyer, Billig, \& Hofschire, 2004).

For instance, Meyer, Billig, and Hofschire (2004) conducted a quasi-experimental study comparing the performance of Michigan service-learning participants on tests from the Michigan Educational Assessment Program (MEAP) and on measures related to involvement in academic learning. Their results showed statistically significant differences in scores on the fifth-grade social studies MEAP, with the service-learning students scoring higher than the students not participating in service-learning. The study also found that younger service-learning students scored significantly higher cognitive engagement scores than the students not engaged in service-learning; among older 
students, service-learning participants demonstrated greater effort in English but lower behavioral engagement than the students not engaged in service-learning.

Positive but limited effects in subject matter achievement from service-learning participation were also noted in a recent, large-scale study that employed student panel data from the 1988 to 2000 National Educational Longitudinal Study, or NELS $(n=15,340)$. The purpose of this study was to assess the relationship between high school students' participation in community service and students' performance in mathematics, reading, history, and science (Davila \& Mora, 2007). By analyzing 1992 NELS data on community-service work with the mean characteristics of individuals who were in the eighth grade in 1988, Davila and Mora concluded that students' engagement in community service was related to positive but small gains in scholastic achievement in the areas of mathematics, science, and history. However, no statistically significant relationship was found between community-service participation and students' reading development.

Overall, there appear to be promising findings regarding the relationship between servicelearning participation and students' subject matter learning and performance. However, although most of these studies provide support for service-learning and its positive impact on students' academic performance, they also reveal that the overall effect of the service-learning experience is generally small.

\section{Learning Commitment, Engagement, and Motivation}

Overall, the findings regarding the relationship between service-learning participation and increased school engagement and motivation for learning are consistently positive across studies. Although motivation and engagement are not direct measures of student academic achievement, they are widely considered important mediators for student academic performance and school success. Students who are more motivated to learn and more engaged in school have been found to perform better academically (Deci, 1984; Prince, 2004).

In their quasi-experimental study, Conrad and Hedin (1981) administered a battery of pre-post instruments to the more than 1,000 students (ages 12-19) enrolled in 27 high-performing experiential learning programs as well as to a group of comparable students (matched by age, grade in school, geography, grade-point average, and socioeconomic status) who were not engaged in experiential learning activities. The instruments measured changes in students' attitudes toward school and engagement in learning, as well as several psychological, moral, and social developmental outcomes. Through this quasi-experimental study, Conrad and Hedin found that the students in the experiential learning group expressed higher levels of interest in and motivation for their learning than did the students in the comparison group, although the differences between the two groups were small. They also found that engagement in community-based experiential learning activities exposed students to factors and opportunities that are known to mediate academic achievement, including opportunities for students to act autonomously, develop collegial relationships with adults and peers, and boost their self-esteem and sense of self-efficacy (Conrad \& Hedin, 1981).

Increased motivation toward school and more positive attitudes toward learning have also been reported in several other quasi-experimental studies of service-learning (Brown, Kim, \& Pinhas, 2005; Furco, 2002; Hecht, 2002; Laird \& Black, 1999; Melchior, 1995, 1998; Scales, Blyth, Berkas, \& Kielsmeier, 2000; Scales, Roehlkepartain, Neal, Kielsmeier, \& Benson, 2006). For example, Melchior (1998) analyzed a set of academic-related data pertaining to students enrolled in 17 middle and high schools operating high-quality service-learning programs. Relying on more than 20 measures from pre-post surveys and school records, he noted statistically significant differences between a group of service-learning students $(n=608)$ and a group of comparable students $(n=444)$ not engaged in service-learning in the areas of school engagement and performance in mathematics. Pre-survey assessments had indicated that mathematics was the students' least preferred curricular subject. In his follow-up assessment, Melchior found that most of the academic performance gains 
noted among service-learning students had disappeared one year later. However, student engagement in learning remained significantly higher for service-learning students than for students who did not participate in service-learning (Melchior, 1998).

Scales, Blyth, Berkas, and Kielsmeier (2000) also reported significant pre-post changes in motivation for learning, engagement in school, and overall academic success among middle school students $(n=1,153)$ enrolled in three schools. At the start of the new school year, students were randomly assigned to teams within their schools. The schools then selected one-half of the teams to be service-learning teams and the remainder to serve as control teams that would not participate in a service-learning experience for at least one semester. In addition to social and personal outcomes, the researchers assessed students' commitment to classwork, engagement with school, perceived scholastic competence, and personal sense of intellectual achievement responsibility all through a pre-post instrument (i.e., Survey of Middle School Student Life). When compared to students in the control group, service-learners maintained a stronger pursuit of better grades and showed less decrease over time in their commitment to school work. Through some additional analyses of the data, Scales et al. (2000) found that the number of hours of service-learning (31 or more), along with the amount and type of reflection and students' motivation to engage in community service and service-learning, predicted these outcomes.

In their quasi-experimental study, Scales, Roehlkepartain, Neal, Kielsmeier, and Benson (2006) explored the relationship between the amount of exposure to service-learning and students' academic engagement and overall achievement. A group of middle and high school students $(n=5,136)$ were asked to indicate how many hours, days, or months they participated in community service or service-learning in the last school year, to report their grades (marks) for their academic courses, and to complete a survey (i.e., Search Institute Profiles of Student Life: Attitudes and Behavior Survey) that measures students' commitment to learning, such as achievement motivation, school engagement, and bonding to school. Scales et al. (2006) report that students (from both high and low socioeconomic strata) who engaged in community service or service-learning had significantly higher scores on the commitment to learning scale than did students who did not participate in any kind of service. The researchers also found that students (18\%) involved in a few weeks of servicelearning had better attendance and grades (and by proxy, stronger school connectedness) than did students $(61 \%)$ with no service-learning, but not significantly better than the students $(21 \%)$ with only a few hours of service-learning. Overall, Scales et al. conclude that students' engagement in community service and service-learning enhances their commitment to learning, motivation to achievement, and overall engagement with school.

\section{School Success Indicators}

Other studies have assessed impacts on more general aspects of student academic achievement and educational success. Over the years, the body of research has associated service-learning participation with reductions in disciplinary problems (Calabrese \& Schumer, 1986), improvements in students' school attendance (Follman \& Muldoon, 1997; Melchior, 1998), improvements in students' grades and grade-point averages (Laird \& Black, 1999; Melchior, 1998), and increases in student retention in school (Bridgeland, Dilulio, \& Morison, 2006).

For example, Follman and Muldoon (1997) analyzed data provided by 91 recipients (program directors) of government-sponsored service-learning grants administered by the state of Florida. Collectively, these service-learning programs engaged more than 29,000 primary and secondary students in a wide range of academic service-learning activities. Each grant recipient was asked to produce a report that would include pre-service-learning and post-service-learning comparisons of students' school grade-point averages, absences from school, and discipline/behavior referrals. Follman and Muldoon's analysis found that a large majority of the grant recipients reported that service-learning had positive effects for students' academic development. They found that $62 \%$ of 
the respondents reported decreases in student absenteeism (an average annual decrease of 46 percent), $74 \%$ of respondents indicated pre-post improvement in students' grades (an improved average of .5 points on a scale of $0-4.0$ ), and $68 \%$ of respondents indicated a decrease in student office referrals for classroom misbehavior (an average of $68 \%$ fewer referrals during the academic year).

It should be noted that to determine results, most of these studies measure school success through the use of proxies (e.g., discipline referrals, attendance, grade-point averages). This is because "school success" is a multifaceted, amorphous construct influenced by a variety of factors and therefore is not readily observable or easy to measure. Until more studies are conducted that replicate some of the existing studies, researchers are limited in their ability to make claims about service-learning's impact on students' school success when they must rely primarily on proxy measures, such as attendance, discipline referrals, and suspensions.

\section{Making the Case for Service-Learning}

Overall, the research to date suggests that service-learning can have positive effects on K-12 students' performance on achievement tests, subject matter knowledge acquisition, engagement in school, motivation for learning, school attendance, and grades. However, the nature of evidence in the field points to an important issue regarding the strength of the case for service-learning. Proponents of service-learning (e.g., individuals "within" the field) tend to be strong advocates of service-learning, mostly because they have witnessed positive outcomes of the practice and have bought into its promise and potential. Many of the researchers of service-learning are also proponents who believe that service-learning, when done well, can produce a host of positive outcomes for students. In fact, many of the studies in the literature are those which service-learning practitioners have conducted of their own programs or evaluation studies that have been driven by the goals and agendas of funders.

A consequence of building a body of research primarily from advocates is that the level of scrutiny applied to the evidence for service-learning is likely lower than might be applied by skeptics and other detractors. However, as Furco and Root (2010) suggest, making the case for K-12 servicelearning in an era of testing and accountability will require "the kinds of research designs that can raise the status of service-learning as an evidence-based practice" (p. 16).

In 2003, the U.S. Department of Education's Institute of Education Sciences (IES) developed a set of research criteria that allow educators to distinguish between levels of evidence for educational practices. As shown in Table 1, findings that are accepted as evidence of the effectiveness of practice must be based on studies that included random assignment of subjects, a treatment and one or more comparison groups, uniform implementation of practice at multiple sites, control over external factors, and replication. Practices whose effectiveness has been demonstrated through research that meets these criteria can be designated as evidence-based and are placed on the Department's What Works Clearinghouse. There is much debate regarding the over-reliance of IES criteria on positivistic research orientations that focus on experimental approaches and are limited to outcomes that can be measured quantitatively (Johnson, 2009). As Johnson (2009) suggests, the positivistic approach is built on standardization and generalization and thus inherently limits the ability to understand the nature of educational practices in the nuanced and idiosyncratic settings of the real world. However, the Department of Education's definition of evidence-based practice has strongly influenced federal recommendations for instructional practice, federal grant-making decisions, and district and school policies. 
16 | International Journal of Research on Service-Learning and Community Engagement

Table 1. U.S. Department of Education Qualifications for Research that Produces "Evidence"

\begin{tabular}{|c|c|c|c|}
\hline & Evidence & Possible Evidence & No Evidence \\
\hline Comparison & $\begin{array}{l}\text { Two or more groups } \\
\text { compared (treatment and } \\
\text { control group) }\end{array}$ & $\begin{array}{l}\text { Two or more groups } \\
\text { compared treatment and } \\
\text { control group or matched } \\
\text { comparison groups }\end{array}$ & $\begin{array}{l}\text { Only one group is } \\
\text { studied (Lack of control } \\
\text { or comparison group) }\end{array}$ \\
\hline Random Assignment & $\begin{array}{l}\text { Subjects are assigned } \\
\text { randomly to groups }\end{array}$ & $\begin{array}{l}\text { Subjects are assigned } \\
\text { randomly to groups or } \\
\text { randomization is } \\
\text { approximated. }\end{array}$ & Lack of randomization \\
\hline $\begin{array}{l}\text { Consistent } \\
\text { Treatment }\end{array}$ & $\begin{array}{l}\text { Treatment is implemented } \\
\text { uniformly across the group }\end{array}$ & $\begin{array}{l}\text { Minimal variation in } \\
\text { treatment across members of } \\
\text { the treatment group }\end{array}$ & $\begin{array}{l}\text { Gross variation in } \\
\text { treatment across } \\
\text { members of the } \\
\text { treatment group }\end{array}$ \\
\hline Multiple Sites & $\begin{array}{l}\text { Treatment is offered at more } \\
\text { than one "site" }\end{array}$ & $\begin{array}{l}\text { Treatment is offered at one or } \\
\text { more sites }\end{array}$ & $\begin{array}{l}\text { Treatment is limited to } \\
\text { one site or is site specific }\end{array}$ \\
\hline Replication & $\begin{array}{l}\text { The study is replicated } \\
\text { (multiple cases) using the } \\
\text { same procedures }\end{array}$ & $\begin{array}{l}\text { The study is replicated but } \\
\text { not in the exact same manner }\end{array}$ & $\begin{array}{l}\text { The study is not } \\
\text { replicated; one set of } \\
\text { data are used to draw } \\
\text { conclusions }\end{array}$ \\
\hline Controls & $\begin{array}{l}\text { External influences are } \\
\text { controlled for in both } \\
\text { treatment and comparison } \\
\text { groups }\end{array}$ & $\begin{array}{l}\text { Most or all external } \\
\text { influences are controlled for } \\
\text { in both treatment and } \\
\text { comparison groups }\end{array}$ & $\begin{array}{l}\text { There are few or no } \\
\text { controls for influences } \\
\text { that might contaminate } \\
\text { the findings }\end{array}$ \\
\hline
\end{tabular}

Note: Adapted from Identifying and Implementing Educational Practices Supported by Rigorous Evidence: A User Friendly Guide, 2003, U.S. Department of Education Institute of Education Sciences and the National Center for Education Evaluation and Regional Assistance.

The implications for research on K-12 service-learning are clear. The K-12 service-learning field must build on existing studies that have provided "possible evidence" and employ research investigations that can garner the kinds of evidence that can convince skeptics that service-learning has value. Specifically, the goal must be to conduct research that can meet the criteria for evidence regarding the effects of service-learning on essential outcomes of schooling, including academic achievement and school success. As several researchers (e.g., Billig \& Furco, 2001; Bringle, 2003) have noted previously, more attention needs to be paid to garnering more generalizable findings through the employment of experimental design, valid measures, and more sophisticated analyses. Additionally, because of the need for replication, the research agenda for K-12 service-learning will need to incorporate a series of studies that will build on each other and fully meet the standards of scientific inquiry.

The challenges to meeting the criteria for evidence in the study of service-learning are welldocumented in the service-learning literature (e.g., see Billig \& Waterman, 2003). Standardizing service-learning practice, randomly assigning study participants or study sites, and controlling for external influences on students are all difficult standards to achieve when conducting studies in K-12 school settings. In addition, external limitations on researchers, due to districts' institutional review board requirements and other human subjects protection requirements (e.g., securing active parent consent), pose other challenges that limit researchers' capacities to conduct research that can produce 
evidence. Nevertheless, if service-learning is to be more fully embraced by the broader K-12 education community, research studies that can produce evidence that can demonstrate positive effects on students' academic achievement and school success need to be supported and conducted.

\section{Strategies for Building the Evidence}

In light of the existing body of research produced to date as well as the current educational and fiscal climates, there are specific issues that should be addressed regarding future research endeavors that will help build a stronger case for K-12 service-learning. Over the past two decades, a number of service-learning research agendas have been published (Billig \& Eyler, 2003; Billig \& Furco, 2001; Giles \& Eyler, 1998; Giles, Honnett, \& Migliore, 1991, 2002). While some have focused on identifying the important research questions that can advance the field (e.g., Billig \& Furco, 2001; Giles, Honnett, \& Migliore, 1991), others have proposed research priorities, methodologies, and strategies that need to be employed to increase the quantity and quality of the research (Billig \& Eyler, 2003). Although the service-learning research agendas have increasingly incorporated more complex questions and issues, those questions and issues have not changed fundamentally (Giles, 2010).

For instance, in 2001, Billig and Furco published an agenda for K-12 service-learning research which proposed a set of "questions that should guide the research in the next decade" (p. 273). The questions were clustered within five overarching questions focused on deepening the understanding of the impact of service-learning on student academic achievement and cognitive development. The five overarching questions were:

- What is the impact of service-learning on student achievement?

- What are the impacts of service-learning on students' acquisition of specific content knowledge and skills?

- What are the impacts of service-learning on the development of critical thinking skills?

- Are the cognitive processes involved in service-learning different for acquisition of critical thinking skills and content knowledge?

- To what extent does service-learning impact lifelong learning?

In addition to questions, research agendas have also suggested needed methodologies for building the evidence for service-learning and its impact on students' academic achievement and school success.

Conduct more large-scale experiments. The service-learning field needs to develop a plan for implementing a series of large-scale random control trials that can allow for sophisticated quantitative analyses to assess the relationship between service-learning and students' academic achievement and school success. While such studies are difficult to conduct within the servicelearning context, they provide important information that cannot be garnered through smaller scale studies or non-experimental investigations. These studies are also expensive to conduct. If the field is serious about building its evidence base and making the case, then large investments in research must be made. For purposes of comparison, approximately \$25 million has been spent to study the effects of cooperative learning.

Collect data on implementation. Along with assessing program outcomes, all research studies should take into account program quality and ensure that the nature of the service-learning experience is explained fully. Unfortunately, because of the lack of program detail that is present in many studies that appear in the service-learning literature, it is unclear if the activity (i.e., intervention) studied was service-learning, community service, or some other type of communitybased experience. The standards of research in the field should include an expectation that all study 
reports include a clear definition of service-learning and a full discussion of the key programmatic components of the service-learning practice under study.

Build and test theories. One of the strongest criticisms of service-learning research is the lack of attention paid to theory exploration and development. Service-learning draws from a number of well-developed theoretical frameworks of learning and development (e.g., experiential learning, situated cognition, youth development, constructivism, etc.), yet many studies are atheoretical. Perhaps a more serious problem is that the field has yet to organize assumptions drawn from different theories of learning and development into a coherent framework that is unique to servicelearning and can guide investigations into its impacts. The service-learning field has much to gain from studying the ways in which research on other similar pedagogies (e.g., problem-based learning) has drawn on a coherent theory of learning and/or development. Attention to strong theoretical and conceptual development is an important way to help those outside the field view service-learning research as more legitimate. No service-learning study should be funded unless it makes some strong connection to an existing or new theory.

Replicate high-quality studies. Researchers should work to verify the purported academic benefits of service-leaning that appear in the literature by replicating components of completed highquality service-learning studies. This process might involve replicating particular forms of servicelearning in new contexts, replicating particular instruments and measures that were used, or replicating study designs. Replication is a critical component of evidence building, and the servicelearning field needs to have a plan for replicating its highest quality studies.

Connect with and learn from kindred fields. Project-based learning, problem-based learning, inquiry-based learning, and other pedagogies that contain some or most of the elements of servicelearning have managed to build stronger research bases and garner convincing evidence regarding how these instructional approaches impact students' academic achievement. The service-learning field can benefit from exploring the research within these kindred pedagogies and to perhaps replicate some of the studies in those fields using service-learning as the instructional practice. In addition, studies that compare academic outcomes between service-learning and kindred pedagogies should be explored. If it is found that there is no difference in outcomes between inquiry-based learning and service-learning, then it can be argued that service-learning is equally as effective as a practice that already has a relatively strong evidence base.

Focus on empirical evidence of learning. Much of the research in the field has relied on data gathered from proxies for school success or self-reported gains in academic achievement rather than on actual observed achievement gains. While attitudinal and self-report surveys that assess how much students believe they have learned from service-learning have value for assessing participants' views and opinions, they do not provide verifiable data regarding how much students have actually learned. Future studies of service-learning need to incorporate data points that provide observable achievement data. Proxies and self-reported data can continue to be used to provide additional validation of the data and verification of the results through triangulation.

Include measures of learning based on current cognitive psychology. Most current assessments of student learning reflect a conception that knowledge and skills are represented in memory as discrete, decontextualized facts, concepts, and procedures acquired in incremental fashion. However, advances in cognitive science indicate instead that knowledge is represented in the form of complex, actively constructed structures (i.e., schema). In addition, current views of the learning process represent it not as a step-by-step progression but as the attainment of expertise. Features of expert knowledge include coherent declarative knowledge within the domain of expertise. In addition, expert knowledge appears to be organized around general principles or big ideas, rather than discrete facts and concept. Experts have greater procedural and conditional knowledge within their domain of expertise; that is, they appear to have declarative schema that are linked to rules for using knowledge and to an understanding of when and where knowledge should be applied. Finally, expert knowledge includes sophisticated metacognition, that is, strategies for applying knowledge and for monitoring the effectiveness of one's performance. The findings from 
cognitive science regarding the nature of knowledge and the learning process have implications for the types of measures of learning that should be used in service-learning research. In addition to test scores and grades, measures of service-learning impacts on subject area mastery should include performance assessments and constructed response tasks that can capture the complex nature of knowledge. Growth in subject area knowledge should be examined in light of expertise theory, that is, with reference to characteristics of expert knowledge and the progressions individuals follow in acquiring expertise. Finally, measures of academic impacts of service-learning should include tasks, such as think-alouds during problem solving, that require students to make their thinking explicit and reveal metacognition (i.e., what they do with their knowledge).

Conduct longitudinal and developmental studies. Few school-based instructional practices or educational programs are life-changing. Yet, we somehow expect to prove that a service-learning experience (which on average lasts for 20 hours) can improve students' academic achievement and enhance their overall success in school. Aside from setting realistic expectations for what servicelearning can and cannot accomplish, the service-learning field could benefit much from understanding the longer term impacts of the practice and how students at different stages of development and maturity benefit (or do not benefit) from service-learning. It is very likely that the impacts of service-learning (academic or otherwise) might not be realized for months or years after the service-learning experience ends. Yet, with few exceptions, the research has focused primarily on assessing short-term outcomes of service-learning. Longitudinal research conducted on higher education students has shown some promising findings regarding the longer term impacts of servicelearning (Astin, Vogelgesang, Ikeda, \& Yee, 2000; Stukas, Snyder, \& Clary, 1999).

Conduct secondary analyses. The service-learning field should make better use of the various existing datasets that are housed within federal agencies, state departments of education, and research centers. Many service-learning researchers have datasets on student academic issues that could benefit from secondary analyses or be used for meta-analyses. In addition, data from the National Center for Educational Statistics (NCES), the Corporation for National Service, the National Education Longitudinal Study (NELS), Trends in International Mathematics and Science Study (TIMMS), the Program for International Student Assessment (PISA), and other programs and units can provide useful data on student achievement and program trends that can be aligned with trends within the service-learning field. More robust incentives should be provided to mine these existing datasets to produce new findings for the field.

Explore connections to existing and new funding sources. Funding that specifically supports studies of service-learning is unlikely to be available any time soon. To move the research agenda forward, the field needs to be creative in exploring research funding in various program areas (e.g., violence prevention, health, education, etc.) which can be tapped to build the evidence base for service-learning. For example, the Obama administration has launched an initiative for states to develop and test assessments that are more apt measures of complex cognitive outcomes, particularly performance assessments. In addition, the administration supports other rigorous cross-school measures, for example, student performance on district pre- and post-tests in subjects not currently tested, such as civics. Even if the funding does not tap academic achievement or school success outcomes (the focus of this agenda), pursuing these funds to conduct rigorous studies of servicelearning can help strengthen the theoretical and methodological base for the field and further strengthen the overall evidence base.

\section{Conclusion}

While the diversity of potential benefits of service-learning has led to its adoption in a variety of contexts, it has also limited the opportunity to build a coherent knowledge base about its impacts. In addition, the fact that many studies have been conducted by advocates of service-learning has led to an acceptance of less rigorous evidence of its effects than has been needed to persuade skeptics. 
Given current expectations for school and teacher accountability, as well as Department of Education criteria for what should count as evidence of effectiveness, a new research agenda is needed that calls for rigorous scientific studies that address the essential question of how school-based servicelearning impacts students' academic achievement and school success.

The strategies presented above extend the issues and questions raised in previous servicelearning research agendas, with the aim of moving the field forward. Despite almost 30 years of practice, the limits of researchers' knowledge continually place them in the position of having to make the case for service-learning in K-12 schools. The questions about the academic merits of service-learning and the criticisms of the quality of service-learning research heard today are very much the same as those that have been heard and written about for more than a decade.

As the field ventures into the next decade of advancing the research on K-12 service-learning, will researchers and practitioners push themselves more to meet the standards of the current, dominant research paradigm in order to garner the legitimacy they have so long desired, or will they continue to push back on the dominant research paradigm and rely on broader research orientations to guide their research endeavors? Will they be able to demonstrate in ten years that the body of their research meets the standards and principles of high-quality inquiry and has built the evidence base needed to make the case for service-learning in K-12 education? Will they look back on those ten years and be able to show the tremendous, quality improvements they have made in the research, or will they be discussing the same criticisms of the research that have challenged the field over the last two decades?

It is time to address and act on the much-documented challenges of conducting research on $\mathrm{K}-12$ service-learning. Great progress has been made in recent years, but much more work needs to be done to improve the quality of the research, especially as it pertains to student academic outcomes. By building on what is known, tapping the robust service-learning talent from across the country, and working together to achieve a common set of goals, the case for service-learning in K-12 education can be greatly strengthened.

\section{Acknowledgements}

I wish to express my thanks and gratitude to Shelley Billig, Linda Caswell, Janet Eyler, Kateryna Kent, Tom Marcinkowski, Alan Melchior, Caryn Pernu, Susan Root, and Jim Kielsmeier for their input and assistance with this report.

\section{Notes}

1. The estimate for the number of studies in 2000 is based on comprehensive reviews of the service-learning literature regarding K-12 education (Billig, 2000), higher education (Eyler, Giles, \& Gray, 1999), and teacher education (Anderson, 2000). The estimate for the number of studies in 2010 is based on a count of updated reviews by Eyler and Giles (2003), research studies published in key research-oriented academic journals (e.g., Michigan Journal of Community Service-Learning), and recent summaries of research in the field (Anderson, 2008; Furco, 2010; Root, 2009). The estimates for 2000 and 2010 provide a minimum rather than an actual number of available studies. It should be noted that only English-language studies were considered for this estimation.

2. The remaining studies focus on service-learning's impacts on faculty, institutions, communities, or higher education students, or on issues concerning service-learning implementation, institutionalization, or international programming. 


\section{Correspondence}

Correspondence concerning this article should be addressed to: Andrew Furco, Office for Public Engagement, University of Minnesota, 120 Morrill Hall/100 Church St. SE, Minneapolis, MN 55455; afurco@umn.edu

\section{References}

Akujobi, C., \& Simmons, R. (1997). An assessment of elementary school service-learning teaching method: Using service-learning goals. NSEE Quarterly, 23(2), 19-28.

Astin, A., Vogelgesang, L. J., Ikeda, E. K., and Yee, J. A. (2002). How service learning affects students: Executive summary. Retrieved March 8, 2002, from UCLA Service-Learning Clearing House Project, Higher Education Research Institute.

Billig, S. H. (2000). The evidence on K-12 based service-learning: The evidence builds. Phi Delta Kappan. 81(9), 658-664.

Billig, S. H. \& Eyler, J. (Eds.). (2003). Deconstructing service-learning: Research exploring context, participation, and impacts. Greenwich, CT: Information Age Publishing.

Billig, S. H. \& Furco, A. (Eds.). (2002). Service-learning through a multidisciplinary lens. Greenwich, CT: Information Age Publishing.

Billig, S.H., \& Waterman, A. S. (2003). Studying service-learning. Mahwah, N.J.: L. Erlbaum Associates.

Bridgeland, J. M., Dilulio, J. J., \& Morison, K. B. (2006). The silent epidemic: Perspectives of high school dropouts. Civic Enterprises \& Peter D. Hart Research Associates.

Bringle, R. G. (2003). Enhancing theory-based research on service-learning. In S. H. Billig \& J. Eyler (Eds.), Deconstructing service-learning: Research exploring context, participation, and impacts (pp. 3-21). Greenwich, CT: Information Age Publishing.

Brown, S., Kim, W., \& Pinhas, S. (2005). Texas Title IV service learning evaluation, 2004-05. Denver, CO: RMC Research Corporation.

Calabrese, R. L., \& Schumer, H. (1986). The effects of service activities on adolescent alienation. Adolescence, 21, 675-687.

Conrad, D., \& Hedin, D. (1981). National assessment of experiential education: Final report. St. Paul, MN: Center for Youth Development and Research, University of Minnesota.

Davila, A., \& Mora. M. (2004) English-language skills and the earnings of self-employed immigrants in the United States: A Note. Industrial Relations, 43(2), 386-391.

Deci, E. L. (1980). The psychology of self-determination. Lexington, MA.: Lexington Books.

Eyler, J., Giles, D. E., Jr., \& Gray, C. J. (1999). At a glance: What we know about the effects of service-learning on students, faculty, institutions, and communities, 1993-1999. Nashville, TN: Vanderbilt University.

Follman, J., \& Muldoon, K. (1997). Florida Learn \& Serve 1995-96: What were the outcomes? NASSP Bulletin, 81, 29.

Furco, A. \& Billig, S.H. (Eds.) (2001). Service-learning: The essence of the pedagogy. Greenwich, CT: Information Age Publishing.

Furco, A. \& Root, S. (2010). Research demonstrates the value of service learning. Phi Delta Kappan, 91(5), 16-20.

Furco, A. (2002). Is service-learning really better than community service? A study of high school service program outcomes. In A. Furco \& S. Billig (Eds.), Service-learning: The essence of the pedagogy. Greenwich, CT: Information Age Publishing.

Giles, D. E., Jr., Honnett, E.P., \& Migliore, S. (1991). Research agenda for combining service and learning in the 1990s. Raleigh, NC: National Society for Internships and Experiential Education. 
22 | International Journal of Research on Service-Learning and Community Engagement

Giles, D. E., Jr., \& Eyler, J. (1998). A service-learning research agenda for the next five years. In R. Rhoads \& J.P.F. Howards (Eds.), Academic service-learning: A pedagogy of action and reflection (pp. 65-72). San Francisco: Jossey-Bass.

Giles, D. E., Jr. (2010). Journey to service-learning research: Agendas, accomplishments and aspirations. In J. Keshen, B. A. Holland, \& B. E. Moely (Eds.), Research for what: Making engaged scholarship matter (pp. 203-221). Greenwich, CT: Information Age Publishing.

Hecht, D. (2002). A study of the effects of participation in the helper model of service-learning in early adolescence. Unpublished report, Center for Advanced Study in Education, City University of New York.

Johnson, R. B. (2009). Toward a more inclusive "scientific research in education." Educational Researcher, 38(6), 449-457.

Klute, M. M., \& Billig, S. H. (2002). The impact of service-learning on MEAP: A large-scale study of Michigan Learn and Serve grantees. Denver, CO: RMC Research Corporation.

Kraft, N., \& Wheeler, J. (2003). Service-learning and resilience in disaffected youth: A research study. In S. H. Billig \& J. Eyler (Eds.), Advances in service-learning research: Vol. 3.

Deconstructing service-learning: Research exploring context, participation, and impacts (pp. 213-238). Greenwich, CT: Information Age Publishers.

Laird, M. \& Black, S. (1999). Service-learning evaluation project: Program effects for at risk students. Oakbrook, IL: Lions Quest.

Melchior, A. (1995). National evaluation of Serve-America: Final report. Waltham, MA.: Center for Human Resources, Brandeis University.

Melchior, A. (1998). National evaluation of Learn and Serve America school and community-based programs: Final report. Prepared for the Corporation for National Service. Waltham, MA: Center for Human Resources, Brandeis University.

Melchior, A, \& Bailis, L. N. (2002). Impact of service-learning on civic attitudes and behaviors of middle and high school youth: Findings from three national evaluations. In A. Furco \& S. H. Billig (Eds.), Advances in service-learning research: Vol.1. Service-learning: The essence of the pedagogy (pp. 201-222). Greenwich, CT: Information Age Publishers.

Meyer, S., Billig, S., \& Hofschire, L. (2004). The impact of K-12 school-based service-learning on academic achievement and student engagement in Michigan. In M. Welch \& S. Billig (Eds.), New perspectives in service-learning: Research to enhance the field. Greenwich, CT: Information Age Publishing.

National Service-Learning Partnership. (2003). We make the road by walking. National ServiceLearning Partnership.

Prince, M. (2004). Does active learning work? A review of the research. Journal of Engineering Education, 93(3), 223-231.

Scales, P. C., Blyth, D. A., Berkas, T. H., \& Kielsmeier, J. C. (2000). The effects of service-learning on middle school students' social responsibility and academic success. Journal of Early Adolescence, 20 (3), 332-358.

Scales, P. C., Roehlkepartain, E. C., Neal, M., Kielsmeier, J. C., \& Benson, P. L. (2006). Reducing academic achievement gaps: The role of community service and service learning. Journal of Experiential Education, 29, 38-60.

Stukas, A., Snyder, M., \& Clary, E. (1999). The effects of "mandatory volunteerism" on intentions to volunteer. Psychological Science, 10(1), 59-64.

Weiler, D., LaGoy, A., Crane, E. \& Rovner, A. (1998). An evaluation of K-12 service-learning in California: Phase ii final report. Emeryville, CA: RPP International with the Search Institute. 